\title{
A Comparative Clinical Study on the Effect of Dhanyaka Kalka and Dhanyaka Avalehya with Anupana of Sharkara mixed Tandulodaka in Garbhini Chardi
}

\author{
Research Article
}

\section{Upasana Nath $^{1^{*}}$, Kalpana Sharma $^{2}$}

1. Lecturer, Prasuti Tantra Stree Roga Department,

Nitishwar Ayurvedic Medical College \& Hospital, Muzaffarpur, Bihar

2. Professor \& HOD, Department of Prasuti Tantra and Stree Roga, Rishikul Campus, Haridwar, Uttarakhand

\begin{abstract}
Garbhini Chardi (vomiting in pregnancy) is a blazing issue in obstetric enactment. About 50-60\% of all pregnant females agonize from vomiting in pregnancy most apparently in first trimester. If not tackled effectively before or in time, it may affect the quality of life of pregnant woman and pregnancy consequences. Ayurvedic classics have described many formulations for management of Garbhini Chardi. In this study Dhanyaka kalka and Dhanyaka Avaleha was taken both with Anupana of Sharkara mixed Tandulodaka. Aim: To compare the effect of Dhanyaka Kalka and Dhanyaka Avaleha with Anupana of Sharkara mixed with Tandulodaka in Garbhini Chardi. Materials and Methods: Single blind clinical study with pre-test and post-test was designed. 60 patients complaining of Chardi in $1^{\text {st }}$ trimester were randomly divided into the two groups: Group A and Group B, each comprising of 30 patients. Medicine used for Group A was Dhanyaka Kalka with Anupana of Sharkara Mixed Tandulodaka (rice, water or gruel) and medicine used for Group B was Dhanyaka Avaleha with Anupana of Sharkara mixed Tandulodaka. Those cases, which were in regular follow ups for 5 weeks were taken for clinical study. The criteria of assessment were mainly on the symptomatic relief. Intermediate follow ups were recorded at interval of two weeks. Results: In Group A, overall percentage relief in chief complains was calculated as $59.44 \%$ whereas in Group B this value was $66.5 \%$. Conclusion: In present clinical study efficacy of Dhanyaka Avaleha has been proven beneficial in comparison to Dhanyaka Kalka. The trial drug is highly significant in the management of Garbhini Chardi. This study needs to be done on large scale and for longer duration.
\end{abstract}

\section{Keywords: Dhanyak a Avaleha, Dhanyaka Kalka, Garbhini Chardi and Tandulodaka}

\section{Introduction}

A Woman has been the torchbearer of the society for centuries. She is responsible for the miracle of birth. Pregnancy is truly an amazing and glorious time in women's life.

The growing foetus depends entirely on mother's body for all its requirements therefore a pregnant lady must take measures to remain healthy and well-nourished to have a healthy child which is a motive of every human being. Garbhini Chardi is mentioned as Vyakta Garbha Lakshana with other Lakshanas like Artava Adarshan, Asyasamsravana, Arochaka, Gurugatrata, Stanamandala Krishnata etc $(1,2)$. All these Lakshana are seen due to presence of Garbha. When Chardi is seen as a Lakshana there is no much harm on growing foetus as well as mother, as this is included in physiological changes (3). When vomiting during pregnancy is seen as excess, it may

*Corresponding Author:

\section{Upasana Nath}

Flat No\# C2, Plot No\# B52,

Manoram Punj Apartment, Budha Colony,

Patna, Bihar, India - 800001

E-mail id: drupasanadubey@gmail.com cause discomfort and irritation for the pregnant lady (4). It is mandatory to take care and treat these conditions in initial stage and prevent further complications.

Emesis Gravidarum is a worldwide common obstetrical problem seen in the first trimester of pregnancy in about $50-60 \%$ of pregnant women. Nausea and vomiting tend to be worse in the morning termed Morning sickness, they frequently continue throughout the day. For such physiological alterations, if proper care is not given, it may lead to complication like severe dehydration, tiredness, weight loss, etc. which may affect mother and growing foetus. So one should take care to treat this condition in initial stage and prevent complications (5).

While explaining regarding the Chikitsa in Garbhini; Acharyas have mentioned that she should be given things which are easily palatable, Hridaya and the one which is liked by her (6). Keeping this view an attempt is being made to control Garbhini Chardi on principles of Ayurvedic formulation called Dhanyaka Kalka and Dhanyaka Avaleha both with Anupana of Sharkara mixed Tandulodaka (7). These formulations can be easily prepared and administered. These two formulations are having Hridaya, Rochana, Deepaniya, Grahi, Pachana properties (8). 


\section{Study Objective}

In the view of various limitations of use and complication associated with drug use in the management of vomiting during pregnancy, the present research work is planned with the following objectives:

- To evaluate the effect of Dhanyaka Kalka with Anupana of Sharkara Mixed Tandulodaka in Garbhini Chardi.

- To evaluate the effect of Dhanyaka Avaleha with Anupana of Sharkara Mixed Tandulodaka in Garbhini Chardi.

- To compare the effect of both Dhanyaka Kalka and Dhanyaka Avaleha with Anupana of Sharkara Mixed Tandulodaka in Garbhini Chardi.

\section{Materials and Methods \\ Design of study}

This is a single-blind observational clinical study with pre-test and post-test design.

\section{Source of data}

Patients attending OPD and IPD of the Department of Prasuti Tantra and Stree Roga, Rishikul Campus, Haridwar has been randomly selected. A comparative clinical study has been conducted on 70 selected pregnant women, having classical symptomatology of Chardi in Garbhavasta.

\section{Reason for dropouts}

Initially 70 patients were registered for the study out of which 10 patients were dropped out in due course. Out of dropped 10 patients, 3 patients dropped due to miscarriage, 1 patient had twin pregnancy which was diagnosed later and was excluded from the study and 6 patients dropped out due to unknown reason.

\section{Inclusion criteria}

Patients diagnosed as Garbhini Chardi between 19 to 36 years of age in first-trimester of pregnancy in both primi and multi Gravida.

\section{Exclusion criteria}

- Patients in whom Chardi seen in second and third trimester.

- Patients with hyperemesis gravidarum.

- Patients with twin pregnancy and vesicular mole.

- Vomiting caused due to other systemic disorders like peptic ulcer, appendicitis,

- Hypertension, uraemia etc

\section{Criteria for Withdrawal}

- Personal matters

- Intercurrent illness

- Aggravation of complaints

- Any other difficulties

\section{Assessment Criteria}

In this section, parameter of study, criteria of scoring and criteria for assessment of therapy has been discussed.

\section{Parameters of the Study}

- Nausea and Chardi Vega, which are chief complain in Garbhini Chardi, are fundamental criteria for clinical assessment of improvement in patients.

- Nausea and Chardi Vega, itself are subjective parameters and it is hardly possible to fix it in available objective parameters, thus in such a case physician has to believe totally and keeps faith in the patients saying, even then for research purpose these Criteria has to be classified properly.

Criteria for scoring of Chief complains - In present study Nausea and Chardi Vega has been graded on its increasing severity on scale having gradation $0-3$ [Table 1].

Table 1: Criteria of scoring Chief complaints

\begin{tabular}{|l|l|l|}
\hline Complaint & Scale & Criteria of scaling \\
\hline \multirow{5}{*}{ Nausea } & 0 & Nil \\
\cline { 2 - 3 } & 1 & $\begin{array}{l}\text { Mild (Feel Discomfort, does } \\
\text { routine work) }\end{array}$ \\
\cline { 2 - 3 } & 2 & $\begin{array}{l}\text { Moderate (Impact normal } \\
\text { routine work) }\end{array}$ \\
\cline { 2 - 3 } $\begin{array}{l}\text { Chardi } \\
\text { Vega }\end{array}$ & 3 & $\begin{array}{l}\text { Severe (Unable to do routine } \\
\text { work properly) }\end{array}$ \\
\cline { 2 - 3 } & 1 & $\begin{array}{l}\text { Nil } \\
\text { day) (One to two times in a }\end{array}$ \\
\cline { 2 - 3 } & 2 & $\begin{array}{l}\text { Moderate (Three to four } \\
\text { times in a day) }\end{array}$ \\
\cline { 2 - 3 } & 3 & $\begin{array}{l}\text { Severe (More than four } \\
\text { times in a day) }\end{array}$ \\
\hline
\end{tabular}

\section{Criteria for scoring of Associated complains}

In Present study Loss of Appetite, Headache, Constipation, Fatigue, Weight and $\mathrm{Hb} \%$ are used as associated complains. Associated complains Appetite, Headache, Constipation and Fatigue has been graded on its increasing severity on scale having gradation 0-3 [Table 2].

Table 2: Criteria for scaling Associated complaints

\begin{tabular}{|c|c|l|}
\hline Complaint & Scale & \multicolumn{1}{|c|}{ Criteria of scaling } \\
\hline \multirow{5}{*}{ Appetite } & 0 & Good \\
\cline { 2 - 3 } & 1 & Average \\
\cline { 2 - 3 } & 2 & Below average \\
\cline { 2 - 3 } Headache & 3 & Less \\
\cline { 2 - 3 } & 0 & Nil (Not Present) \\
\cline { 2 - 3 } $\begin{array}{c}\text { Constipa- } \\
\text { tion }\end{array}$ & 2 & Mild (Occasionally) \\
\cline { 2 - 3 } & 3 & Moderate (1-2 times in a day) \\
\cline { 2 - 3 } & 0 & Severe (2 times in a day) \\
\cline { 2 - 3 } & 2 & $\begin{array}{l}\text { Mild (Frequency once in day } \\
\text { but hard stool pass) }\end{array}$ \\
\hline \multirow{4}{*}{$\begin{array}{l}\text { Moderate (Frequency of stool } \\
\text { alternative day and patient } \\
\text { feels difficulty in defecation) }\end{array}$} \\
\cline { 2 - 3 } & 3 & $\begin{array}{l}\text { Severe (Patient cannot pass } \\
\text { stool without any purgative- } \\
\text { agent. Even after 3-4 days) }\end{array}$ \\
\hline
\end{tabular}




\begin{tabular}{|c|c|l|}
\hline Complaint & Scale & \multicolumn{1}{c|}{ Criteria of scaling } \\
\hline \multirow{4}{*}{ Fatigue } & 0 & Nil ( No Fatigue) \\
\cline { 2 - 3 } & 1 & Mild (morning Fatigue) \\
\cline { 2 - 3 } & 2 & Moderate (2 times in a day) \\
\cline { 2 - 3 } & 3 & Severe (Always) \\
\hline
\end{tabular}

\section{Follow up and Results}

Those cases, which were in regular follow ups for 5 weeks were taken for clinical study. Those who were not regular in follow up were excluded from study. The criteria of assessment were mainly on the symptomatic relief. Intermediate follow ups were recorded at interval of two weeks. Observation for relief in sign and symptoms in first follow up was done. Last follow up was recorded to see the improvement in sign and symptoms

\section{Criteria for selection of drug}

Dhanyaka Kalka and Dhanyaka Avaleha both with Anupana of Sharkara Mixed Tandulodaka has been selected for the present study. The drug preparation has been done at Ras Shastra Department of Rishikul Mini pharmacy, Haridwar.

The Selection of drug for the study was based on the following fundamentals points-

- Easy Availability of well identified drug in sufficient quantity

- Easy Administration

- Economy

- Palatability

\section{Determination of dose with duration}

Following dose had been given to patients based on the selected group:

Group A: Dhanyaka Kalka with Anupana of Sharkara Mixed Tandulodaka was given initially for 2 weeks. Dose: 1/2 TSF (3gram) 6 hourly i.e. 4 times in a day.

Group B: Dhanyaka Avaleha with Anupana of Sharkara Mixed Tandulodaka was given initially for 2 weeks. Dose: 1 TSF (6 gram) 6 hourly i.e. 4 times in a day.

Tandul was given to the patients of both above groups in Yavkutta form. Tandulodaka consumption was approximately $80 \mathrm{ml}$ per day (i.e $20 \mathrm{ml}$ in each dose). It had 10 grams of Y avkutta Tandul and $80 \mathrm{ml}$ of Udaka (Ratio of Tandul to Udaka should be 1:8). Dose of Sharkara was 1 TSF (6 gram) mixed with $80 \mathrm{ml}$ of Tandulodaka

\section{Criteria for Upashaya}

Cured - Patients having effect of $67-100 \%$

Improved - Patients having effect of 34-66 \%

Not cured - Patients having effect of $0-33 \%$

\section{Results}

Effect of treatment was assessed both clinically as well as based on laboratory parameters. Following are effect of treatment on individual signs and symptoms of chief complain, associated complains and investigation parameters [Table 3].
Table 3: Statistical comparison between effect of dhanyaka kalka and dhanyaka avalehya on chief complaint during study.

\begin{tabular}{|l|l|l|l|l|}
\hline \multirow{2}{*}{$\begin{array}{l}\text { Statistical } \\
\text { Properties }\end{array}$} & \multicolumn{2}{|l|}{ Dhanyaka Kalka } & \multicolumn{2}{l|}{ Dhanyaka Avaleha } \\
\cline { 2 - 5 } & Nausea & $\begin{array}{l}\text { Chardi } \\
\text { Vega }\end{array}$ & Nausea & $\begin{array}{l}\text { Chardi } \\
\text { Vega }\end{array}$ \\
\hline Mean of BT & 1.56 & 1.80 & 1.53 & 1.80 \\
\hline Mean of AT & 0.70 & 0.73 & 0.53 & 0.60 \\
\hline $\begin{array}{l}\text { Difference } \\
\text { (BT-AT) }\end{array}$ & 0.86 & 1.07 & 1.00 & 1.20 \\
\hline S.E. & 0.128 & 0.122 & 0.09 & 0.089 \\
\hline $\boldsymbol{t}$ Value & 5.47 & 5.96 & 5.80 & 6.70 \\
\hline \% change & $55.31 \%$ & $59.25 \%$ & $65.21 \%$ & $68.42 \%$ \\
\hline $\boldsymbol{p}$ Value & $<0.001$ & $<0.001$ & $<0.001$ & $<0.001$ \\
\hline
\end{tabular}

In Group A, overall percentage relief in chief complains has been calculated as $59.44 \%$ whereas in Group B this value is $66.5 \%$ [Figure 1]. Hence, in present clinical study efficacy of Dhanyaka A valeha has been proven beneficial in comparison to Dhanyaka Kalka.

\section{On Chief Symptoms}

The effect of drugs on chief complains and associated complains are shown below:

Nausea: In Group A, 50\% patients got cured, $23.33 \%$ patients got improvement remaining $26.66 \%$ patients remain unchanged at end of the study. In Group B, 53\% patients got cured, $30 \%$ patients got improvement remaining $16.66 \%$ patients remain unchanged at end of the study.

Chardi Vega: In Group A, 50\% patients got cured, $26.66 \%$ patients got improvement remaining $23.33 \%$ patients remain unchanged at end of the study. In Group B, $53.33 \%$ patients got cured, $33.33 \%$ patients got improvement remaining $13.33 \%$ patients remain unchanged at end of the study.

\section{On Associated sign and symptoms}

In Group A, 30\% patients got cured, $46.66 \%$ patients got improvement remaining $23.33 \%$ patients remain unchanged at end of the study.

In Group B, 40\% patients got cured, 40\% patients got improvement remaining $20 \%$ patients remain unchanged at end of the study.

Figure 1: Group A Vs Group B-Comparison of percentage of relief

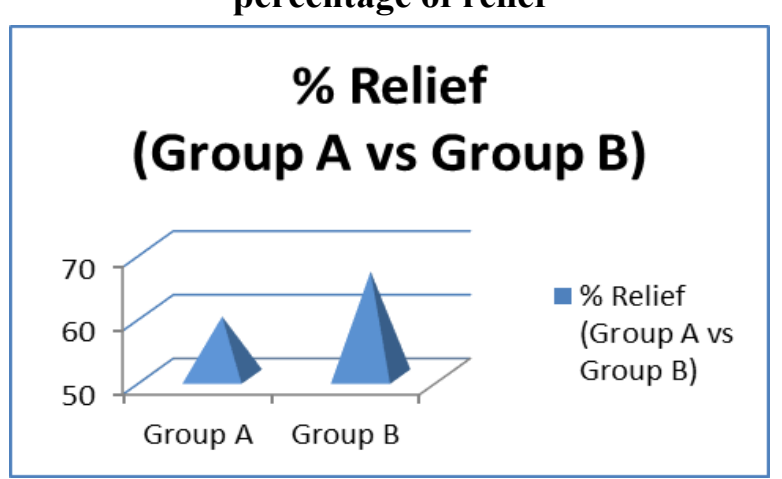


Impact of therapy has been concluded better in Group A compared to Group B even on the basis of percentage change in chief symptoms and associated symptoms [Figure 2 and Figure 3].

Figure 2: Group A Vs Group B - Percentage change in symptoms.

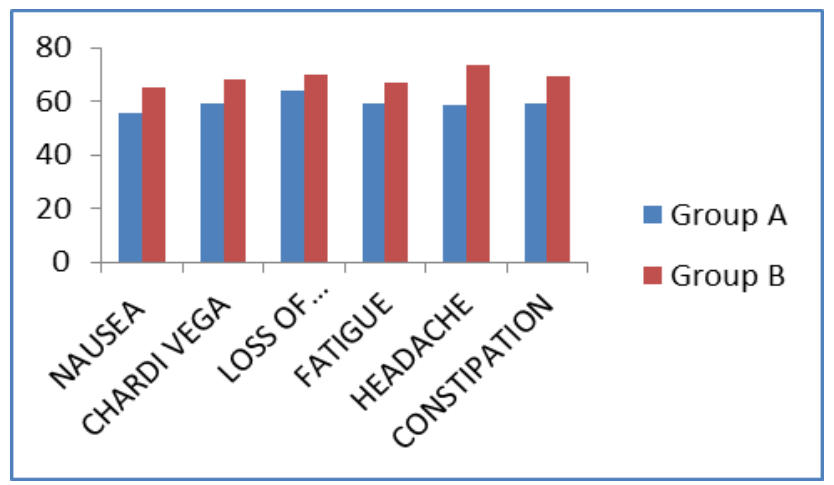

Figure 2: Group A Vs Group B - Percentage change in weight and $\mathrm{Hb} \%$.

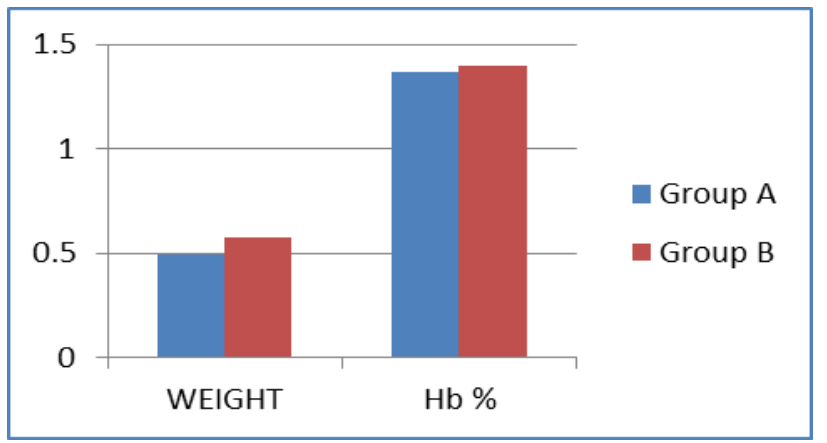

\section{Discussion}

The present research work has been framed to undertake a critical literary, conceptual, clinical and trial drugs study to evaluate and compare the effect of Dhanyaka Kalka and Dhanyaka Avaleha with Anupana of Sharkara mixed Tandulodaka in Garbhini Chardi.

Dhanyaka is taken in the form of Kalka and Avaleha. As per research result, Dhanyaka Avaleha is slightly more effective than Dhanyaka Kalka. In my outlook, Avaleha is much better form as it is prepared from dry seeds and kalka prepared from leaves so as per availability Dhanyaka seeds are always available and Dhanyaka leaves is available in particular seasons. The transportation of Kalka is not easy as its self-life is one day and transportation of Avaleha is much easier as its self-life is one year [Table 4]. Kalka is among the Panchvidha Kashaya Kalpana and as per its Guna, it is Guru than Kwatha. Avaleha is prepared from Kwatha, so it is Laghu than Kalka. Kashaya is kept on fire to become thick thus by the Samyoga of Agni also it is Lagu than Kalka. Therefore assimilation and absorption of Avaleha is better than Kalka.

Dhanyaka contains Madhura Rasa, Tikta Rasa, Kashaya Rasa, Katu Rasa, Ushna veerya and Madhura Vipaka (9). Due to presence of Madhura, Tikta and Kashaya Rasa, along with Madhura Vipaka it is Vata and Pitta shamaka (10). Due to presence of Katu Rasa and Ushna Veerya, it is Kapha Vata Shamaka $(11,12)$.
Table 4: Propertied of drugs for comparison

\begin{tabular}{|l|l|l|}
\hline Properties & $\begin{array}{l}\text { Dhanyaka } \\
\text { Kalka }\end{array}$ & $\begin{array}{l}\text { Dhanyaka } \\
\text { Avaleha }\end{array}$ \\
\hline Part-used & $\begin{array}{l}\text { Dhanyaka } \\
\text { leaves }\end{array}$ & Dhanyaka seeds \\
\hline $\begin{array}{l}\text { Availabilit } \\
\text { y }\end{array}$ & $\begin{array}{l}\text { In particular } \\
\text { season }\end{array}$ & Every season \\
\hline Storage & Not easy & Easy \\
\hline Self-life & One day & One year \\
\hline Guna & Guru & Laghu \\
\hline
\end{tabular}

Madhura Rasa acts as Bringhana and Tarpana which does Pitta Shamaka and helps in nourishing the Dhatus there by doing Poshana of the Garbha (13). Tikta Rasa is Aruchi Nashaka. It increases perception of taste by activating the taste receptors. It acts as Agnideepaka, Ahara Pachaka, Daha Shamaka, Trishna Nigrahana, Krimihara and maintains texture of Twaka and Mamsa. In Garbhini Chardi, patient complains of Aruchi, Agnimandya, Daha, Trishna and dryness in mouth. Tikta Rasa by its action helps in curing all these Lakshanas and helps in controlling Chardi (14). Kashaya Rasa is Sansamana and Sangrahi. It has antiinflammatory action, it helps in absorption of excess Kleda .It pacifies Kapha Pitta and Rakta Dosha. Predominantly it contains stagnation property thus this Rasa has Chardi Hara property (15). Katu Rasa acts as Mukha Shodhaka, Agnideepaka, Indriya Prasadaka, Srotovisrutikaraka and Kapha Shamaka. By Mukha Shodhaka property, it cures Aruchi by increasing the perception of taste. By Agnideepana property, it cures Ama and does Ahara Pachana which helps in formation of Rasadi Dhatus by which proper Poshana to the Garbha is maintained. Ushna Virya is Kapha Shamaka and Madhura Vipaka is Vata Shamaka. Tandulodaka along with Sharkara has Sheeta potency, and Sheetal Drava is always Stambhaka (16). It acts as good vehicle in bringing out pharmacological actions of other ingredients in the formulation with the presence of sugar in the drug it becomes palatable as the taste receptors are stimulated which helps in excessive secretion of saliva. It is readily assimilated and accepted by the stomach hence uptake of the nutrients take place easily Due to Laghu and Snigdha Guna of Dhanyaka, its assimilation and absorption becomes quick by the stomach, its action is by modulating vestibular impulses to the autonomic centers of the central nervous system and also by increasing the intestinal motility by preventing stasis of food in the stomach for longer time and has gastro kinetic effect i.e. It helps in moving the contents of stomach earlier. So it can be used as adjuvant with other drugs that interfere with gastric motility as it acts like Vatanulomaka and helps in controlling Vata there by controlling Chardi (17).

As vomiting is caused due to carbohydrate starvation presence of fructose, glucose in the drug helps to supplement it thus preventing vomiting (18). Dhanyaka and Sharkara contain calcium, iron, Carbohydrate, vitamins like B, C etc these are very much essential during pregnancy as there is increased demand of these during pregnancy. This will also help 
for the proper development of the fetus and she will not suffer from vomiting, anemia etc conditions during pregnancy. Thus Dhanyaka with its property of Brihmana, Ruchivardhaka, Agnideepaka, Amapachaka and Dhatu Poshaka, maintains Vata in normal proportion there by controlling Chardi and nourishing Garbha (19).

Since it is small sample study, a clinical study on large sample is required before coming into any conclusion regarding the total pharmacodynamics and pharmacokinetics of the drug. But the outcome of present study definitely gives as inspiration to proceed with the study of this drug in disease Garbhini Chardi for research scholars in this field in future.

\section{Conclusion}

Vomiting in pregnancy is the commonest disorder found in between 19 to 24 years of age. It is found more in primigravida and also women who had nausea and vomiting in their first pregnancy are more prone to have such symptoms in subsequent pregnancy.

By the clinical trial on 60 patients with 30 patients in each group (Group A-Dhanyaka kalka with Anupana of Sharkara Mixed with Tandulodaka) and Group B (Dhanyaka Avaleha with Anupana of Sharkara Mixed with Tandulodaka), the results in group B was more effective in reducing Chardi Vega, Nausea, Loss of appetite, Constipation, Fatigue, Headache and Hemoglobin percentage than Group A. Both the groups were effective in maintaining the weight of the Garbhini. Research efforts can be instituted in larger samples for further precision.

\section{References}

1. Agnivesha, Charaka, Dridhbala, Charaka Samhita, Sharira Sthana, Mahatigarbhava kranti adhyaya 4/16, elaborated vidyotini hindi commentary edited by Pandit Kasha Nath Shastri and Dr Gorakhnath Chaturvedi, Reprinted edition 1998, Chaukhambha Bharti Academy, Varanasi, Pg No-874.

2. Maharshi Sushruta, Sushruta, Sushruta samhita, Sharira Sthana, Gharbhavkranti Sharira Adhyaya3/12, edited by Kaviraj Dr Ambikadutta Shastri, $11^{\text {th }}$ edition 1997, Chaukhambha Sanskrita Bhavan, Varanasi, Pg No-22.

3. Kashyapa, Maricha; Kashyapa Samhita (1998), Vriddha Jeevaka Rev Vatsya with Vidyotani Hindi commentary by Satyapala Bhisagacharya Chaukambha Sanaskrit Sansthan, Varanasi. Antarvartini Chikitsa Adhyay-10/118, Pg No-300.

4. Dutta D. C., Text Book of Obstetrics, Edited by Hiralal Konar, 3rd Edition, New Central Book Agency (P) ltd., Calcutta. Pg No-52.

5. Madhavakara; Madhava Nidana, with Madhukosha commentary by Vijayarakshita and Srikantha Datta,'Vimala' Madhukara Hindi commentary by Dr Brahmananda Tripathi, Chardi Nidana Adhyaya, Chaukhamba Subharati Prakashana, Varanasi, Pg No-408
6. Vagbhatacharya; Ashtanga Sangraha with Hindi Vyakhya by Kaviraj Atrideva Gupta; Reprint Edition, 1993; Krishnadas Academy, Varanasi, Uttar Pradesh. Sharira Sthana 2/62,63 Pg No-242

7. Yogaratnakara, Vidyotani Hindi Tika by Vaidya Lakshmi Pati Shastri Edited by Bhisagratna Brahma shankar Shastri Chaukhambha Prakashan Edition 2012 Stree Roga Chikitsa - Shloka number 11 Pg No-421.

8. Bhavamishra, Bhavaprakasha, Edited with vidyotini English commentary by Prof. K.R. Srikantha Murthy, Chaukhamba Orientalia, Varanasi, Reprint 2011, Chapter number 1, Shloka number-88 Pg No172

9. Raj nighantu Dravyagunaprakashika " Hindi Vyakhayopait " Vyakhayakar - Dr. Indradev Tripathy Introduction by Acharya Vishwanath Dwivedi Chowkhambha Krishnadas Academy, Varanasi Reprint 2010 Pg No.-141.

10. Nighantu Aadarsh by Shree Bapalal Vaidhya, Chaukambha Bharti Academy, Jeerakadi Varga, Volume 1, Pg. No-697.

11. Dhanvantari Nighantu, Edited by Prof. Priya Vrata Sharma, Translated by Dr Guru Prasad Sharma, Chaukhambha Orientalia, Varanasi, Reprint 2008, Shatpushpadi Varga, Pg No.82.

12. Dravyaguna Vijnana (fundamental Principles of pharmacotherapeutics (Fundamentals Principles of Pharmacotherapeutics Ayurveda) by Dr J.L.Sastry M.D. (ayu) forwarded by Prof.K.C.Chunekar Chaukhambha orientalia Edition 2012 Volume 3 Pg. No.-265.

13. Pathak Nimish L, Kasture Sanjay B, Bhatt Nayna $M$ and Rathod Jaimik D, Phytopharmacological Properties of Coriander Sativum as a Potential Medicinal Tree: An Overview, Journal of Applied Phytopharmacological science, 2011, Pg. No.-2

14. Harita Samhita edited by Bhisagaratna Pandit Shri Bramha Shankar Mishra, (Part-2), 11 ${ }^{\text {th }}$ Edition, 2007, Chaukhambha Sanskrita Bhawana, Varanasi, Pg. No-141

15. Sharandhara Samhita "Jeevanprada" Sa-vimarsh, Hindi Vakhya Samhita by Dr Shrimati Shailaja Shrivastava, Poorvakhand, Roga Gadhna Adhyaya7/28, Chaukhambha Orientalia, Varanasi, edition 2001, Pg no-76.

16. Kaidev Nighantu by Acharya Priya Vrat Sharma, Chaukhambha orientalia, Varanasi Reprint 2009, Aushadhi Varga Shloka No- 1195-1197, Pg No 220-221.

17. Ibidem (Reference No-5), Charaka Samhita, Chardi Chikitsa 20/7, 10,12,14,18, Pg No-579, 580.

18. Guide to a healthy pregnancy by Dr. Kamini Rao 2006 Edition, Pg No-1

19. Kashyapa, Maricha; Kashyapa Samhita (1998), Vriddha Jeevaka Rev Vatsya with Vidyotani Hindi commentary by Satyapala Bhisagacharya Chaukambha Sanaskrit Sansthan, Varanasi, Pg No.454. 